
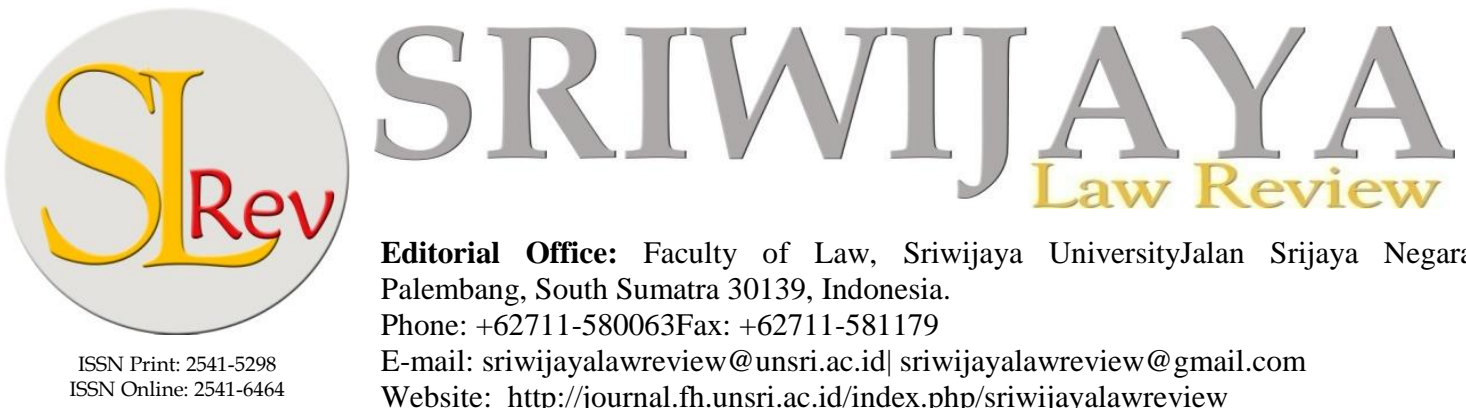

Editorial Office: Faculty of Law, Sriwijaya UniversityJalan Srijaya Negara, Palembang, South Sumatra 30139, Indonesia. Phone: +62711-580063Fax: +62711-581179

E-mail: sriwijayalawreview@unsri.ac.id|sriwijayalawreview@gmail.com Website: http://journal.fh.unsri.ac.id/index.php/sriwijayalawreview

\title{
THE PROTECTION OF CONSUMER RIGHTS FOR AVIATION SAFETY AND SECURITY IN INDONESIA AND MALAYSIA
}

\begin{abstract}
Annalisa Yahanan ${ }^{1}$, Febrian $^{2}$, and Rohani Abdul Rahim ${ }^{3}$
Abstract: Indonesia and Malaysia have a good potency for cooperation in aviation industry. It can be seen in the establishing two aviation companies namely PT. Indonesia Air Asia and Malindo which both are low-cost carrier. These aviation industries are categorized as low-cost carrier, however safety and security are absolute factors because these are rights for consumers. This article will describe further about safety and security standard; protecting the rights for consumers in connection with safety aviation in Indonesia and Malaysia from the Consumer Protection Law and the Aviation Law. As a result of the research shows that safety standard passenger for air transportation in airport covers information and safety facility in the shape of availability of the emergency safety tools (fires, accidents and natural disasters); information, area and health facility; and healthcare workers. Moreover, safety standards for passenger in an aircraft include information and safety facility in the shape of availability information and the emergency safety tools for passenger in an aircraft. The protection for consumer rights for safety flight in Indonesia as follows: aviation industry has obligation to fulfill minimum standard of safety and security; consumers must be safety from false information which raises concern; aircraft operation which endanger of the passenger; and consumer protection in operating the electronic device which endanger flight. On the other hand, the law of consumer rights in Malaysia relating to aviation are ruled under the Aviation Law as a result of the Warsaw Convention 1929. In conclusion, the verdict of consumer rights related to security aviation begins when the passenger enter to an aircraft, in the aircraft, and by the time they get off the plane.
\end{abstract}

Keywords: aviation safety; consumer rights; protection.

\section{ARTICLE HISTORY :}

Received:

Jan 4, 2017; Reviewed: Jan 11, 2017

Accepted:

Jan 18, 2017; Published: Jan 30, 2017

1 Faculty of Law, Sriwijaya University, Palembang-South Sumatera, Indonesia

E-mail: annalisa_yahanan@yahoo.com

2 Faculty of Law, Sriwijaya University, Palembang-South Sumatera, Indonesia

E-mail:febrian_zen@yahoo.com.sg

3 Faculty of Law, National University of Malaysia, Bangi, Selangor, Malaysia

E-mail:rar@ukm.edu.my

\section{INTRODUCTION}

Indonesia and Malaysia are neighbour which have a lot of business cooperation in joint venture commercial flights, for example PT. Indonesia Air Asia ${ }^{1}$ and Malindo Air

Kisah Sukses Bos Air Asia, http://kisah-orang sukses. blogspot.com/2013/10/kisah-sukses-bosair-asia.html (retrieved: July 14, 2014). In 2004, Air Asia constitute joint venture enterprise in Indonesia. Air Asia control 49\% shares. In Indonesia, Air Asia venture with PT. Awair to perform low-cost carrier under the name of Indonesia Air Asia. For example, Indonesia Air Asia operated using code QZ7558 (CKG-JOG). 
(Malaysia Indonesia). ${ }^{2}$ Both industrial aviations are low-cost carrier, ${ }^{3}$ known as no frill. The joint venture has make a history reflecting tight relationship between the two states. $^{4}$

The concept of low-cost carrier is enjoyed not only for high-class income but also for lower-class income. ${ }^{5}$ Thus, flight tariff influences the demand for flight ticket in Indonesia and Malaysia. ${ }^{6}$

In order to increase the business, one on the hand, the industrial aviation in Indonesia and Malaysia must consider high market share, ${ }^{7}$ although it is also has intense compe-

2 Malindo Air is a joint venture between National Aerospace and Defense Industries (51\% share of Malaysia) and Lion Air of Indonesia (49\% of Indonesia), http://www.beritasatu.com/ekonomi/ 140085-2014 malindo-air-ekspansi-ke-empatnegara.html, (retrieved: Dec 25, 2016.)

3 LCC concept used the term "No Frill" (low cost) in the 2009 Law No. 1 on Aviation.

4 Malindo Air, syarikat penerbangan kos rendah baru Malaysia, http://www.sinarharian.com.my/ bisnes/malindo-air-syarikat-penerbangan-kosrendah-baru-malaysia-1.84114. (retrieved: Apr 24, 2016).

5 Kamal Halili, et al., Kajian Polisi dan Perundangan Berkaitan Penerbangan dan Perkhidmatan, Kode Project: UKM-UP-JKKBG-08-04-017, Fakulti Undang-Undang Universiti Kebangsaan Malaysia, Bangi, Selangor, 2010. p 15.

6 Arya Nugraha, Adam Air, LCC, dan Statistik Penerbangan Domestik, http://aryanugraha. wordpress.com/2007/01/04/adam-air-lcc-danstatistik-penerbangan-domestik/. (retrieved: Feb 20, 2016.)

7 According to the Ministry of Transportation of the Republic of Indonesia, Bagian Pengembangan Usaha Pengangkutan Udara Bidang Perusahaan dan Bagian Penerbangan Dalam Negeri Berjadwal, Jakarta 2015, there are 16 airlines in Indonesia, namely PT. Garuda Indonesia, PT. Batik Air Indonesia, PT. Mandala Airlines, PT. Sriwijaya Air, PT. Kal Star Aviation, PT. Trigana air service, PT. Travel Express Aviation, PT. Indonesia Air Transport, PT. NAM Air, PT. Mandala Airlines, PT. Indonesia Air Asia, PT. Dirgantara Air Service, PT. Lion Mentari Airline, PT. Wings tition and high risk. Many commercial airlines in Indonesia are insolvent because they do not have ability to compete, ${ }^{8}$ therefore it affects to the industrial aviations are unable to operate. ${ }^{9}$

On the other hand, the role of online booking is recognized by airlines to increase potential growth based on their survey, especially for their marketing. ${ }^{10}$ It can be

Abadi Airlines, PT. Travira Air and PT. Citilink Indonesia.

8 For example Adam Air Airline, once the aircraft crashed it immediately dispersed, no longer in operation. Read H.K. Martono and Achmad Sudiro, Hukum Angkutan Udara Berdasarkan UU RI No. 1 Tahun 2009, Cetakan kedua, Rajawali Pers, Jakarta, 2011, p. 15.

9 Flights companies were declared bankrupt, among others: PT. Adam SkyConnection Airlines (Adam Air), PT. Bouraq Indonesia Airline; PT. Jatayu Airlines; PT. Sempati Air Transport; PT. Star Air; PT. Linus Airways Indonesia; PT. Mandala Airlines Indonesiadan PT. Metro Batavia. PT. Mandala Airlines Indonesia was declared bankrupt in 2011. However Mandala Airline returned to the Indonesian airline industry after being taken over by the Saratoga Group and Tiger Airways. Thus PT. Mandala Airlines Indonesia resumed operations on April 2012 after stopping operations on January 13, 2011 due to the lack of funds and debt. Saratoga Group acquired the shares of the airline Mandala Air of $51 \%$, followed by Singapore airlines, namely Tiger Airways a total of $33 \%$ and the remaining $16 \%$ by existing shareholders (PT. Mandala Airlines Indonesia) and the indebted (creditor). See Saratoga Group Kuasai Mandala Air, http:/bisniskeuangan.kompas.com/ read/2011//20/07112748/Saratoga. Group Kuasai Mandala Air, (retrieved: July 20, 2016). Batavia Air is declared bankrupt by the Commercial Court of Central Jakarta on January 31, 2013. See Batavia Air Resmi Pailit Bangkrut Stop Operasional, http://www.idberitakita.com/2013/. See Annalisa Yahanan, "Liabiliti Syarikat Pengangkut Udara Komersial dan Hak Penumpang Berhubung Kelewatan di Bawah Undang-Undang Penerbangan Indonesia, Universiti Kebangsaan Malaysia, Tesis, 2015, pp 69-72.

10 David Gilbert, David Child \& Marion Bennet, "A Qualilative study of the current practices of "no frills' airlines operating in the UK'. Journal of Vacation Marketing, volume 7, Issue 4, April 2001. 
seen in the Middle East, for example, online booking for low-cost carriers must be supplemented by the airlines. ${ }^{11}$

The industrial aviation in Malaysia also improves their consumer service to grow up their industry, for instance Malaysia Airline System (MAS) state industrial aviation, and Air Asia, private industrial aviation. ${ }^{12}$ Air Asia also suffered financial loss as a result of the flight accident in AirAsia Indonesia QZ8501 route Surabaya-Singapura on 28 December 2014 and the disappearance of MH 370 on 8 March 2014 from Kuala Lumpur to Beijing.

The growing of industrial aviation in Malaysia can be seen by establishing some industrial aviations, for example Berjaya Air, Eaglexpress, Firefly, Malindo Airways, MASwings, MHS Aviation, Sabah Air, and Weststar Aviation. ${ }^{13}$

Aircraft business is more preferable for consumer than other transportation system. The most reason for consumer is time efficiency. ${ }^{14}$ Thus, aircraft transportations both in Indonesia $^{15}$ and Malaysia are

11 James Rajasekar, Unnikammu Moideenkutty, "Oman Air: Challenges of repositioning through business level strategy", Asian Journal of Management Case, Volume 4, Issue 2, 2007. p 120.

12 Sen Ze \& Jayne Ng, The Air Asia Story, Kisah Maskapai Tersukses di Asia, Ufuk Publishing House, Jakarta, 2007. pp 22-23.

${ }^{13}$ https://id.wikipedia.org/wiki/Daftar_maskapai_pene rbangan_Malaysia, (retrieved: Dec 17, 2016).

14 Wamenhub: Transportasi Udara Lebih Diminati Dibandingkan Darat, http://indosuryaresearch. com/details.php?go=news\&id=6052_IndosuryaResearch-news-Wamenhub:-Transportasi-UdaraLebih-Diminati-Dibandingkan-Darat (retrieved: Aug 10, 2014).

15 Central Statistics Agency (BPS) states that the number of air passengers on January-October 2015 reached 67.46 million, up $12.75 \%$ compared to the same period in 2014 amounted to 59.83 million. While the number of air passengers both domestically and internationally in a number of air- growing every year. Competition between aircraft enterprises and high demand must have serious concern from the enterprises particularly safety and security because they constitute consumer rights and must be protected.

The protection for good faith purchaser in sale and purchase agreement, in Indonesia, are secured under Article 1341, 1491, 1492 the Indonesian Civil Code. Furthermore, the agreement must be rational and should be implemented in good faith as provided in the Article 1338 paragraph (3) the Indonesian Civil Code. The settings of those chapters are applied for aircraft consumers to get the aviation safety right. ${ }^{16}$

Today every country are challenged to improve their science and technology. The mastery of science and technology in every sectors will affect to increase complex in all fields, ${ }^{17}$ such as in aviation sector. Time efficiency and technology advancement in aircraft transportation will give benefit to enterprise aviation's earnings. ${ }^{18}$

Benefit are the first aim for the enterprises in Indonesia and Malaysia, however the protection for rights such as safety and security must not be abandoned.

ports in Indonesia in 2014 reached 72.6 million people, up 5.6\% from 2013 as many as 68.5 million people. See http://www.beritasatu.com/ ekonomi/332030-2016-pertumbuhan-penumpangudara-stagnan.html, (retrieved: Jul 28, 2016.)

16 Hamdaliah, "Perlindungan Hukum Bagi Pihak Pembeli yang Beritikad Baik dalam Jual Beli Tanah", Lambung Mangkurat Law Journal, Volume 1, Issue 2, September 2016. p 167.

17 Arman Anwar, "The Principles Of Liability On Telemedicine Practices", Pattimura Law Journal, Volume 1, Issue 1, September 2016. P 14.

18 E.Saefullah Wiradipradja, "Tanggung jawab perusahaan penerbangan terhadap penumpang menurut hukum udara Indonesia", Jurnal Hukum Bisnis, Volume 25, Issue 1, 2006. p 3. 
These rights, safety and security factors, are compulsory for every enterprises in all services (maximum, middle and minimum services or no frill). ${ }^{19}$

The consumer principally are people who must have protection from the law. Thus, the most appropriate approach in this article is normative and authority approach, namely law is positioned to protect consumer as a weak party and need justice (equal possition) $^{20}$ against other party, the enterprises as a trader. Consumer stipulates the enterprises provide safety which suitable with their requirements and provide optimum services. $^{21}$

This article will discuss minimum services for safety and security in commercial flight. Moreover, the regulation concerning about protection to consumer rights in the light of safety and security in Indonesia and Malaysia are an integral part of this article.

\section{ANALYSIS AND DISCUSSION}

\section{A Standard of Aircraft Passenger Handling Prosedures for Safety and Security in Indonesia}

The safety and security for consumer are provided in the Law Number 1 of 2009 concerning Aviation (Aviation Law 2009). Aviation security means a situation providing protections to aviation against any

19 The 2009 Aviation Law, Article 97 states: (1) the services from schedules commercial air transportation shall at least be categorized in: a. full services; b. medium services; or c. no frills.

20 Sakina Shaik Ahmad Yusoff, Rahmah Ismail and Shamsudin Suhor (sunt.), Pengguna dan Undangundang, Penerbit Universiti Kebangsaan Malaysia, Bangi, 2015. p 23.

21 Rahmah Ismail et al., (sunt.), Undang-Undang Pengguna dan Keadilan Sosial, Penerbit Universiti Kebangsaan Malaysia, Bangi, 2015. p 25. violation of law through utilization of human resources, facilities as well as procedures. ${ }^{22}$ Furthermore, the definition of security and safety in the Government Regulation Number 3 of 2001 on Aviation Security and Safety are a situation for aircraft safety and security operations related to flight plan. $^{23}$ Furthermore, aviation security is a situation realized through free flight operations from disturbances and/or violations against the law. ${ }^{24}$ Aviation safety in the Aviation Law 2009 is a situation in accordance with safety stipulations of air/space territory, aircraft, airports, flight navigation and others facilities. ${ }^{25}$ Moreover, Aviation safety according to the Government Regulation on Aviation Security and Safety is condition is realization of smooth flights related to operations procedures and technical feasibility requirements towards facilities and infrastructure. ${ }^{26}$

Aviation security and safety have important and strategic roles in the aircraft management, thus a state has an authority for the aircraft management. Government is the representative of the state which has a role to develop it in the integrated security and safety civil aviation service system. The developments by the government include arrangements aspect, controling and supervising to the safety and security system for aviation security and safety. ${ }^{27}$

22 The 2009 Aviation Law, Article 1 (49).

23 The Governement Regulation of the Republic of Indonesia No. 3 of 2001 on Aviation Safety and Security, Article 1 (1).

24 Article 1 (2), Note 23.

25 Article 1 (48), Note 23

26 Article 1 (3), Note 23.

27 The Explanation of The 2009 Aviation Law. Aviation is an integrated system consisting of the use of airspace, aircraft, airports, air transport, air na- 
For implementing Article 100 the Aviation Law $2009^{28}$ on scheduled commercial air transportation entity ${ }^{29}$ is stipulated under the Minister of Transportation Regulation No. 38 of 2015 concerning A Standard Services for Aircraft Passenger in Indonesia. ${ }^{30}$

According to the Minister of Transportation Regulation, a standard of aircraft passenger services in airport are handled by ground handling service, $^{31}$ include: ${ }^{32}$

1. Safety services, include:

a. Information and security (information of availability rescuing emergency tools (fire, accident, or natural disaster). For example: road markings, warning traffic light, fire extinguishers (hydrant pilar and APAR), emergency door, emergency exit sign, emergency lamp, fire detection and alarm system and assembly point. A party who has

vigation, safety and security, environment, and support facilities and other public facilities.

${ }^{28}$ Article 100, Note 22, states that further provisions on scheduled commercial air transportation entity shall be stipulated under Ministerial Regulations.

${ }^{29}$ HK. Martono, Kamus Hukum dan Regulasi Penerbangan, Edisi Pertama, PT. Raja Grafindo Persada, Jakarta, 2007. p 306.

30 The Minister of Transportation Regulation No. 38 of 2015 concerning A Domestic Air Passenger Standard Services in Indonesia, Article 3 (1) states that service standards of domestic air passengers at the airport, include: security services; safety, accesibility, comfort, convenience and equality. The Regulation of the Minister of Transportation No. 38 of 2015 is the implementation of Article 100 of the 2009 Aviation Law.

31 Suharto Abdul Majid and Eko Probo D. Warpani, Ground Handling: Manajemen Pelayanan Darat Perusahaan Penerbangan, PT./ Raja Grafindo, Jakarta, 2009. p 6.

32 Apendix I The Minister of Transportation Regulation No. 38 of 2015 on 13 February 2015. responsibility for the safety is airport organizer;

b. Information, area and healthy services (related to information, availability of area and healthy services). For example, the availability of health services in the area, the information for health facility is easily visible and affordable, the health facility, such as feasible to use and not expired first aid supplies and operating hours of health services in accordance with the operating hours of the airport;

c. Health care workers (the person on duty to handle emergency situations). For example, uniformed medical personnel using identification card that is easily visible.

Meanwhile, the type of security services, include:

a. The security facility (security facility at the terminal and surrounding area to prevent crimes). For example, proper security facilities and services to prevent crimes namely the existence of CCTV with recording data storage duration of minimum 30 days;

b. The security officer (officers keeping order and security at airports). For Example, Aviation Security or AVSEC using the identity card that is easily visible.

c. Information security complaint (information to complaint for passenger related to security issues). For example, information in the form of banner contains information where to complaint and a phone number and/or SMS (Call Center) at a strategic and highly visible space. 
2. A standard of safety services for air passenger in aircraft, covers: ${ }^{33}$

a. Information and safety equipment (the availability of information and the safety equipment for air passenger). For example, information and safety equipment that is easily visible and affordable, include: emergency instructions card, flight safety book, prayer cards, life jacket in accordance with passenger capacity, oxygen masks equal to passenger capacity, lanes and emergency doors. This equipments are functionable and in good condition.

b. Medical equipment (the availability of medical equipment used for emergency situations). For example, medical equipment in the form of First Aid.

Before the plane took off, flight attendants will demonstrate the use of such equipment in case of emergency situation and the storage of the equipment.

Concerning to aviation safety and security, every aircraft enterprise must be enlisted by IATA $^{34}$ for Operational Safety Audit (IOSA) as well as IATA Standard Safety Assessment (ISSA). IOSA is an operational safety audit globally focused to operational quality as well as safety management and supervision. For audit, IOSA responsible for flight operation, organization and management system,

33 Apendix II The Minister of Transportation Regulation No. 38 of 2015 on $13^{\text {th }}$ February 2015.

34 IATA is The International Air Transport Association, namely an international air transport organization comprising several airlines. IATA has the headquartered in Montreal, Canada. maintenance of aircraft and aircraft engines, flights departure, checking the cabin, cargo processing and operational security as well as ground handling. The aircraft company if it has met security standards and safety, will receive a certificate Operational Safety Audit (IOSA) from IATA. This means that the company has fulfilled the standard of safety and security International. ${ }^{35}$

The improvement of aviation safety level is necessary for Indonesia should be in line with international aviation standard. ${ }^{36}$ Some airlines in Indonesia have received IOSA certification such as PT. Garuda Indonesia, ${ }^{37}$ and PT. Batik Air Indonesia. ${ }^{38}$ Meanwhile, PT. Sriwijaya Air, PT. Citilink $^{39}$ and Lion Air Group (Lion Air, Wings Air, Malindo Air, Thai Lion) officially registered in IATA Operational Safety Audit (IOSA) and IATA Standard Safety Assessment (ISSA).

\section{Consumer Rights Related to Aviation Security and Safety in Indonesia}

In Indonesia, commercial air transportation has an important role. It is because Indonesia is located between two continents (Asia and Australia) and two oceans (Indian and Pacific). Thus, this geographical situations make the aircraft business has a strategic position in

35 https://id.wikipedia.org/wiki/Garuda_Indonesia, (retrieved: Dec 28, 2016).

36 Ridha Aditya Nugraha, Improving Aviation Safety in Indonesia: How many more accident, Hasanuddin Law Review, Volume 2, Issue 3, December 2016. p 344.

37 https://id.wikipedia.org/wiki/Garuda_Indonesia, (retrieved: Dec 28, 2016).

38 http://www.harnas.co/2016/11/18/batik-air-terima -sertifikat-iosa, (retrieved: Dec 28, 2016).

39 http://www.beritasatu.com/ekonomi/343199-tigamaskapai-berupaya-dapatkan-sertifikat-iosa.html (retrieved: Dec 28, 2016). 
relation between nations, ${ }^{40}$ as well as Indonesia already has air transport agreements with 67 countries including Malaysia. $^{41}$

Scheduled commercial air transport consumers certainly wish to arrive safety at their destination that is the consumer right. Safety and security arrangements for consumer are stipulated in Article 4 the Law No. 8 of 2009 on Consumer Protection which mention the right to safety, security and convenience in using the services. The users can be considered as consumers aviation. ${ }^{42}$ But on the other hand, consumers also have obligations to read or follow instructions and procedures of aviation services, for security and safety. ${ }^{43}$

The Protection of consumer rights related to safety flight, described as follows:

40 HK. Martono, Hukum Penerbangan Berdasarkan UU RI Tahun 2009, Bagian Pertama, CV. Mandar Maju, Bandung, 2009. p 4.

41 Note 40, p 5.

42 The 1999 Law No. 8 on Consumer Protection, Article 4 states: Consumer rights are: a). The right to comfort, security, and safety in consumption of goods and/or services; b). The right to choose of goods and/or services and obtain goods and/or services in accordance with the exchange rate and conditions and guarantees promised; $\mathrm{c}$ ). The right to correct, clear and honest information about the condition of goods and/or services;d). The right to be heard their opinions and complaints on goods and/or services used; e). The right to advocacy, protection and settlement disputes of consumer protection; f). The right to receive guidance and consumer education; g). The right to be treated or serviced properly and honestly and not discriminatory; h). The right to obtain compensation, compensation and/or reimbursement, if the goods and/or services received are not in accordance with the agreement or not as accordingly; i). The rights with the provisions stipulated in other laws and regulations.

43 Article 5 (1), Note 42 state that the obligations of the consumer are: a. To read or follow instructions and procedures about the using of information or utilization goods and/or services, for security and safety.

\section{a. Flight operation}

The Operation of an aircraft may endanger the safety of passengers as it fly beyond the specified path, do not carry safety equipment, and fly over the airspace prohibited according to Article 53 the Aviation Law 2009. ${ }^{44}$ If Article 53 the Aviation Law 2009 is violated then, the airlines penalized imprisonment of 2 (two) years and a maximum fine of $\mathrm{Rp}$ $500,000,000.00$ (five hundred million rupiah). ${ }^{45}$ In the explanation of Article 53 the Aviation Law 2009 noted that activities that endanger the safety of such aircraft, cover: flying outside specified path, do not carry safety equipment, and flying over a forbidden area.

Related to the aviation safety and security, a pilot as captain on the flight shall be dismissed for violating aviation safety and security procedures because he potentially endangers other passengers and flight attendants, such as the

44 Article 53, Note 22 states: (1) Anybody shall be prohibited from operating and/or flying an aircraft that may endanger aircraft safety, endanger the safety of aircraft passenger, crews and cargo, endanger the safety of third party, disturb public security and order; and or damage orher people's propertiy(es). (2) Anybody violating the provisions as meant in item (1) shall be imposed with administrative sanction, as follows: a. freezing of certificate; and/or b. revocation of certificate.

45 Article 411, Note 22 states that anybody flying or operating an aircraft which is intentionally endangering the safety of the aircraft, passenger and goods, and/or citizens or damaging properties of other people as meant in Article 53 shall be condemned with imprisonment for a maximum 2 (two) years and a find of maximum amount of Rp. 500.000.000,00 (five hundred million rupiahs). 
dismissal of Citilink Airline's pilot on December $30^{\text {th }}, 2016 .^{46}$

\section{b. Flight safety standards}

Rights for passenger related to aviation safety and security under the Aviation Law 2009 stated that airlines in Indonesia shall comply with the standards of aviation safety and security. ${ }^{47}$ Thus, the airlines in Indonesia with any type of service (no frill) shall comply the standards of aviation safety and security. ${ }^{48}$ Although it is a minimum service flight, passenger safety remains a priority.

\section{c. Incorrect information}

At the end of 2015 to 2016 was often heard incorrect informations associated with bombs at the airport. In respect of incorrect information about the presence of bombs at the airport, the Aviation Law 2009 provides preventive protection to consumers related to aviation safety and security as user services.

The Ministry of Transportation of the Republic of Indonesia noted that there are 15 (fifteen) ${ }^{49}$ cases of jokes related to bombs threat between the years at several airports in Indonesia.

Currently in Indonesia, irresposible hoax about bringing a bomb on-board aircraft has become popular among passengers. ${ }^{50}$ Although it is questionable how the implementation the sentence to the passengers (consumers) who spread false information, but According to Article 437 the Aviation Law 2009, parties that led to false information (a joke) at the airport and in an aircraft may be subject to a maximum of one year imprisonment. $^{51}$
46 Pilot Citilink yang Diduga Mabuk Dipecat, http://news.okezone.com/read/2016/12/30/337/15 79633/pilot-citilink-yang-diduga-mabuk-dipecat. (retrieved: Jan 3, 2016.)

47 Article 98, Note 22 states: (1) the scheduled commercial air transportation business entity providing service as meant in Article 97 item (1) points $b$ and $c$ shall be a business entity with low cost carrier basis. (2) scheduled commercial air transportation business entity as meant in item (1) shall be obligated to meet aviation safety and secutirity standard.

48 Article 97, Note 22 states: (1) the services from scheduled commercial air transportation shall at least be categorized in: a. full services; b. medium services; or c. no frills. (2) the services as meant in item (1) point $b$ is the minimum services given to the passenger during flight.
49 Informasi Bom Penerbangan Komersial di Indonesia: Berita Bohong Mengganggu Keamanan dan Kenyamanan Penumpang. http:// www.hukumonline.com/berita/baca/lt568e24c702 bd1/waspada-bercanda-soal-bom-di-pesawat-bisadipenjara. (retrieved: Jun 20,2016.)

50 Ridha Aditya Nugraha and Lalin Kovudhikulrungsri, Aviation Legal Issues in Indonesia and Thailand: Towards Better Passengers' Rights in ASEAN, Lokakarya Asosiasi Pengelola Jurnal Hukum Indonesia, Fakultas Hukum Universitas Indonesia, Depok, Nov $21^{\text {th }}$ 2016. P 13

51 Article 437 (1), Note 22 states that anybody providing false information endangering aviation sefety as meant in Article 344 point e, shall be condemned with imprisonment for a maximum 1 (one) year. 
Table 1

Information of Fake Bomb at the Airport in Indonesia

\begin{tabular}{|c|c|c|c|}
\hline Date event & Initial & Airline & Destination \\
\hline April $29^{\text {th }}, 2015$ & IY & Batik Air ID6870 & Cengkareng - Palembang \\
\hline May $1^{\text {st }}, 2015$ & NA & Lion Air JT353 & Padang-Cengkareng \\
\hline May $4^{\text {th }}, 2015$ & SMS. & Lion Air J973 & Batam-Medan \\
\hline May $7^{\text {th }}, 2015$ & SS & Lion Air JT0973 & Batam-Cengkareng \\
\hline May $30^{\text {th }}, 2015$ & $\mathrm{BP}$ & Lion Air JT330 & Cengkareng-Palembang \\
\hline September $7^{\text {th }}, 2015$ & JH & Lion Air JT770 & Cengkareng-Manado \\
\hline September $30^{\text {th }}, 2015$ & FJZ & Citilink QG143 & Kualanamu-Halim \\
\hline Oktober $11^{\text {th }}, 2015$ & RI & Lion Air JT775 & $\begin{array}{l}\text { Sam Ratulangi Manado- } \\
\text { Cengkareng }\end{array}$ \\
\hline December $2^{\text {nd }}, 2015$ & NP & Lion Air JT706 & Surabaya-Makassar. \\
\hline December $24^{\text {th }}, 2015$ & K & Lion Air JT706 & Cengkareng-Taipei \\
\hline December $25^{\text {th }}, 2015$ & $\mathrm{H}$ & Lion Air JT544 & Cengkareng-Yogyakarta \\
\hline December $26^{\text {th }}, 2015$ & $\begin{array}{l}\mathrm{EH}, \mathrm{F}, \\
\mathrm{M}\end{array}$ & Batik Air ID6541 & Kupang-Cengkareng \\
\hline December $31^{\text {st }}, 2015$ & AS & Lion Air JT536. & Cengkareng-Solo \\
\hline January $3^{\text {rd }}, 2016$ & $\mathrm{JM}$ & Lion Air JT663 & Balikpapan-Ujung Pandang \\
\hline January $4^{\text {th }}, 2016$ & SWKS & Airfast VS221 & Surabaya-Timika \\
\hline
\end{tabular}

Sources: The Ministry of Transportation of the Republic of Indonesia, 2015-2016.

\section{d. Electronic devices operation in aircraft}

In Indonesia, the Aviation Law 2009 set the prohibition the operation of electronic equipment by passengers in the aircraft during flight. These acts may endanger flight safety and security and disrupt flight navigation. ${ }^{52} \mathrm{Vi}$ olation of the law may subject to imprisonment for a period of two years or

52 Article 54, Note 22 states that any person during flight on an aircraft shall be prohibited to: a.conducting behavior thaat may endanger aviation safety and security; b.violating in-flight procedures; c.taking or damaging aircraft equipment that may threaten safety; d.conducting a-social behavior; e.disturbing peacefulness; and/or f.operating electronic devices that may disturb flight navigation. a maximum fine of Rp. 200,000,000. (two hundred million rupiah). ${ }^{53}$

In addition, in order to maintain safety and security of the passengers before take-off, the flight attendants demonstrated the use of safety devices and provide information to the passengers about how to open windows and doors in case of emergency.

\section{e. Passport}

Passenger safety when enter international airport is also governed by Article 8 (1) of the Law No. 6 of 2011 on Immigration, stated that every

53 Pasal 412 (5), Note 22 states that any individual during flight onboard an aircraft operating electronic device(s) that is disturbing flight navigation, as meant in Article 54 point $\mathrm{f}$ shall be condemned with imprisonment for a maximum 2 (two) years or a fine of a maximum amount of Rp. 200.000.000,00 (two hundred milion rupiahs). 
person entering or leaving Indonesia territory is required to have a valid passport. Nevertheless, forgery of the passport may also occur because of the high demand of migration and driven by the activity of document forgery syndicate at national and international level. $^{54}$

Passport is a person's identity and a security tool for a country to filter out people who are not allowed such as illegal immigrants and criminals into the territory of Indonesia. ${ }^{55}$ Thus, the consumer rights related to aviation safety are guaranteed under the Law No. 6 of 2011 on Immigration.One function of immigration is the duty of state administration for services and public protection (the explanation of Article 3 of the Law No. 6 of 2011 on Immigration).

Biometric Equipment (validation and measurement using biological characteristics) used in most airports around the world as a consumer safety system at the exit and entry of a country aims to:

i. the program of aviation security in the international level (ICAOInternational Civil Aviation Organization),

ii. Standards for flight security measures,

iii. set the security program quality services and training, and

iv. determine who has the responsibility for coordinating and monitoring the implementation of aviation security

\footnotetext{
${ }^{54}$ Rohani Abdul Rahim, et al., Pemalsuan Dokumen: Isu dan Perlaksanaan Perundangan Imigrasi dalam Kamal Halili Hassan (sunt.) Buruh Asing dan Migrasi-Isu Perundangan, Penerbit Universiti Kebangsaan Malaysia, 2015. pp 191108.

55 Note 5. p 132.
}

program in accordance with the mechanism. $^{56}$

\section{Consumer Rights Related to Aviation Safety and Security Legislation In Ma- laysia}

Safety is one of the rights of consumers as John F. Kennedy said (President of the United States of America) in a hearing of the US Congress known as the Consumer Bill of Rights (Kennedy 1962). ${ }^{57}$ Kennedy acknowledges that consumers are the largest economic group in a country that will receive the impact of every public and private economic decision ${ }^{58}$

Safety for consumer in Malaysia is set under the User Protection Act 1999 [the Act 599], in Part III of the safety of goods and services, in Article 19 states that the Minister may establish safety standards in respect of services or service levels and may specify different safety standards for goods and services or classes of different goods and services.

Thus, the regulation of safety services may also be based on this Article. Furthermore, in Article 20 mentioned that no one was allowed to offer or advertise ser-

56 Rohani Abdul Rahim, et.al. Sekuriti di Pintu Masuk Lapangan Terbang: Isu, Peraturan dan Perundangan Malaysia dalam Kamal Halili Hassan (sunt.) Buruh Asing dan Migrasi-Isu Perundangan, Penerbit Universiti Kebangsaan Malaysia, 2015. pp 39-53.

57 Four consumer rights in court in the United States Congress, known as the Consumer Bill of Rights, namely the right to safety, right to be informed, the right to choose, and the right to be heard.

58 Note 20, dikutip Oleh Sakinah Shaik Ahmad Yusoff, Rahmah Ismail dan Shamsuddin Suhor, Penerbit Universiti Kebangsaan Malaysia, Bangi 2015. p 14 
vices that do not comply with safety standards prescribed under article 19.

Consumers struggle has attracted government attention to change legislation based on consumer protection. ${ }^{59}$ In the interests of consumers of goods and services, the Seventh Malaysia Draft (the RMK 7th) proposed a formulation of the Consumer Protection Act 1999 to ensure safety for consumers when using the services. The government shall amend the Consumer Protection Act to provide appropriate and efficient mechanism for consumers to make claims in case of fraud, injustice and a mistake in a transaction (the RMK 7th: Chapter 16). ${ }^{60}$

In this case the issue of consumer rights associated with concept of safety flight and flight instruments at national and international level. ${ }^{61}$

Safety is the consumers right should be protected by the service provider in case of emergency. Failure to comply the consumer rights generate responsibility to the service providers, but consumers can also be responsible if they are breaking the law.

Malaysia has ratified and signed several major conventions, namely, the Warsaw Convention of 1929, the 1944 Chicago Convention and the Montreal Convention 1999 likewise with Indonesia. The International conventions have been used as a reference to create several legislations

59 Note 20, p 25.

60 Zeti Zuryani Mohd Zakuan, Sakina Shaik Ahmad Yusoff, and Rahmah Ismail (sunt.), Akta Perlindungan Pengguna 1999 (Akta 599) Liabiliti Sivil Peniaga di Malaysia, Penerbit Universiti Kebangsaan Malaysia, Bangi 2015. p 25.

61 Akta Penerbangan Awam 1969 [Akta 3], Akta Pengangkutan Melalui Udara 1974 [Akta 148]. related to aviation in Malaysia, for example the Air Transportation Law 1974 (amendment) 2007 [the Act 148] is a regulation to enforce the conventions ${ }^{62}$ with regard to air transport and to organize the provision related to incidental issues. These rules are to oversee the rules and policies established in the flights contract provided by airlines and passenger. ${ }^{63}$

One form of protection control of consumer rights for aviation safety in Malaysia is the role of the Department of Aviation led by the Director of Civil Aviation which is expressly stated in Article 2 [c] the Law on Civil Aviation 1969, namely to ensure the development of civil aviation safety and orderly throughout Malaysia.

For controling aviation security, the Ministry of Transport can create rules to guarantee a safety flight and safety for passengers from harm as defined in Article 3 [i] the Civil Aviation Act 1969 which states:

"In general, to ensure the safety, efficiency and regularity of aircraft and the safety of aircraft, persons and cargo in it and prevent aircraft from things that harm people and their property"

The implementation to ensure safety flight and passengers when check in at international airport where passengers will pass inspection of biometric machine that can match fingerprint, face shape, eye iris tissue, hand, voice patterns, keystroke dy-

\footnotetext{
62 Certain Conventions is an adaptation from the Warsaw Convention and the Montreal Convention.

63 Preamble Akta Pengangkutan Melalui Udara 1974.
} 
namic and signature. ${ }^{64}$ Meanwhile, some legislation on flights in Malaysia is governed by the following rules:

1. Civil Aviation Act 1969 [Act 3]. This rule services to regulate the national aviation law such as the role of the Director General of Civil Aviation, licensing airlines and so on.

2. The Air Transport Act 1974 [Act 148] is a specific law to enforce the Convention related to air transport and to provide things associated therein

3. The Act of Error Flights 1984 [Act 307] is a specific law to enforce the Convention on errors and other acts committed in aircraft, signed in Tokyo on September 14, 1963. Also following conventions: the Convention for the Suppression of Unlawful Seizure of Aircraft signed at The Hague on 16 December 1970, the Convention for the Suppression of Unlawful Acts Against the Safety of Civil Aviation signed in Montreal on September 23, 1971, and the Protocol for the Suppression of Unlawful Acts of Violence at Airports Serving International Civil Aviation, agreed at Montreal on February 24, 1988.

64 Biometrics is an innovative technology used for fast authentication at the airport on an International flight. Parts of body that can be used in the Biometric machine are fingerprints, facial features, iris tissue in the eye, hand, voice patterns, keystroke dynamic and a signature. Proses Biometrik di Imigrasi Bandara Cengkareng Baru Berlaku Hari Ini, http://oto.detik.com/read/2010/03/31/123419/13 29369/10/proses-biometrik-di-imigrasi-bandaracengkareng-baru-berlaku-hari-ini. (retrieved: Jan 3, 2016).
4. The Airport and Aviation Services Law 1991 [Act 467], is a law to protect assets, rights and obligations of the Government of Malaysia relating to civil aviation in a company, to make the provision of finance for the company, to provide related to staff and for other related matters.

5. The Law Regarding to the International Interests In Aircraft 2006 [Act 659], is an act to implement the Convention on Aviation, and the Protocol of the Convention on International Interests on aviation to Specific Matters in the Aircraft, and the similar rules. It was signed in Cape Town on 16 November 2001.

6. The Civil Aviation Regulations 1996.

\section{CONCLUSION}

In the context of consumer protection associated with consumer rights of aviation safety in Indonesia and in Malaysia, the appropriate measures should and can be taken to achieve justice in order to protect consumer rights related to aviation safety and security. The Consumer Protection Act and the Aviation Law taking side to the consumer must be clear. The interpretation and scope of protection in the law should not be an instrument for exploiting the consumers. The formulation in the law must be balanced between consumers and aviation company. The consumer protection laws in Indonesia and Malaysia are challenging a sophistication of technology and the impact of globalization. 


\section{REFERENCES}

Abdul Majid and Eko Probo D. Warpani. 2009. Ground Handling: Manajemen Pelayanan Darat Perusahaan Penerbangan. Jakarta: PT. Raja Grafindo.

Akta Penerbangan Awam 1969 [Akta 3], Akta Pengangkutan melalui Udara 1974 [Akta 148].

Annalisa Yahanan. 2015. "Liabiliti Syarikat Pengangkut Udara Komersial dan Hak Penumpang Berhubung Kelewatan di bawah Undang-Undang Penerbangan Indonesia, Universiti Kebangsaan Malaysia, Tesis.

Arman Anwar. 2016. "The Principles of Liability on Telemedicine Practices", Pattimura Law Journal, Volume 1, Issue 1.

Arya Nugraha, Adam Air, LCC, dan Statistik Penerbangan Domestik, http://aryanugraha.wordpress.com/2007/0

1/04/adam-air-lcc-dan-statistikpenerbangan-domestik/. (retrieved: Feb 20, 2016).

David Gilbert, David Child \& Marion Bennet. 2001. "A Qualilative Study of The Current Practices of 'No Frills' Airlines Operating in The UK'. Journal of Vacation Marketing, Volume 7, Issue 4.

E. Saefullah Wiradipradja. 2006. "Tanggung Jawab Perusahaan Penerbangan terhadap Penumpang menurut Hukum Udara Indonesia", Jurnal Hukum Bisnis, Volume 25 , Issue 1.

Hamdaliah. 2016. "Perlindungan Hukum Bagi Pihak Pembeli yang Beritikad Baik dalam Jual Beli Tanah", Lambung Mangkurat Law Journal, Volume 1, Issue 2.

HK. Martono. 2007. Pengantar Hukum Udara Nasional dan Internasional, Bagian Pertama. Jakarta: PT. Raja Grafindo Persada.
HK. Martono. 2007. Kamus Hukum dan Regulasi Penerbangan. 1st Edition. Jakarta: PT. Raja Grafindo Persada.

HK. Martono. 2009. Hukum Penerbangan berdasarkan UU RI Tahun 2009. Bandung: CV. Mandar Maju.

HK. Martono and Achmad Sudiro. 2011. Hukum Angkutan Udara Berdasarkan UU RI No. 1 Tahun 2009. 2nd Edition. Jakarta: Rajawali Pers.

http://www.hukumonline.com/berita/baca/ 1t568e24c702bd1/waspada-bercanda soalbom-di-pesawat-bisa-dipenjara. (retrieved: June 20, 2016).

https://id.wikipedia.org/wiki/Daftar_mask apai_penerbangan_Malaysia, (retrieved: Dec 17, 2016).

https://id.wikipedia.org/wiki/Garuda_Indo nesia, (retrieved: Dec 28, 2016).

http://www.harnas.co/2016/11/18/batikair-terima-sertifikat-iosa, (retrieved: Dec 28, 2016).

http://www.beritasatu.com/ekonomi/3431 99-tiga-maskapai-berupaya-dapatkansertifikat-iosa.html, (retrieved: Dec 28, 2016).

http://www.beritasatu.com/ekonomi/1400 85-2014 malindo-air-ekspansi-ke-empatnegara.html, (retrieved: Dec 25, 2016).

http://www.beritasatu.com/ekonomi/3320 30-2016-pertumbuhan-penumpang-udarastagnan.html, (retrieved: Jul 28, 2016).

James Rajasekar \& Unnikammu Moideenkutty, "Oman Air: Challenges of Repositioning Through Business Level Strategy", Asian Journal of Management Cases. Volume 4, Issue 2.

Kamal Halili, et al. 2010. Kajian Polisi dan Perundangan Berkaitan Penerbangan dan Perkhidmatan, Kod Project: UKMUP-JKKBG-08-04-017, Bangi: Fakulti Undang-Undang Universiti Kebangsaan Malaysia. 
Kamal Halili Hassan (sunt.). 2015. Buruh Asing dan Migrasi-Isu Perundangan. Bangi: Penerbit Universiti Kebangsaan Malaysia.

Kisah Sukses Bos Air Asia, http://kisahorangsukses.blogspot.com/2013/10/kisahsukses-bos-air asia.html. (retrieved : July 14, 2014).

Malindo Air, Syarikat Penerbangan Kos Rendah Baru Malaysia,

http://www.sinarharian.com.my/bisnes/ma lindo-air-syarikat-penerbangan-kosrendah-baru malaysia-1.84114. (retrieved: April 24, 2016).

Pilot Citilink yang Diduga Mabuk Dipecat,http://news.okezone.com/read/2016/12 /30/337/1579633/pilot-citilink-yang-

diduga-mabuk-dipecat. (retrieved : Jan $3^{\text {rd }}$, 2016).

Proses Biometrik di Imigrasi Bandara Cengkareng Baru Berlaku Hari Ini, http://oto.detik.com/read/2010/03/31/1234 19/1329369/10/proses-biometrik-diimigrasi-bandara-cengkareng-baruberlaku-hari-ini (retrieved: Jan $3^{\text {rd }}, 2016$ ).

Rahmah Ismail, et al. (sunt.). 2015. Undang-Undang Pengguna dan Keadilan Sosial. Bangi: Penerbit Universiti Kebangsaan Malaysia.

Ridha Aditya Nugraha. 2016. "Improving Aviation Safety in Indonesia: How Many More Accident?". Hasanuddin Law Review, Volume 2, Issue 3.

Ridha Aditya Nugraha and Lalin Kovudhikulrungsri. "Aviation Legal Issues in Indonesia and Thailand: Towards Better Passengers' Rights in ASEAN'. Lokakarya Asosiasi Pengelola Jurnal Hukum Indonesia, Fakultas Hukum Universitas Indonesia, Depok, 21 November 2016.

Sakina Shaik Ahmad Yusoff, Rahmah Ismail and Shamsudin Suhor. 2015. Pengguna dan Undang-undang. Bangi: Penerbit Universiti Kebangsaan Malaysia.
Sen Ze \& Jayne Ng. 2007. The Air Asia Story, Kisah Maskapai Tersukses di Asia. Jakarta: Ufuk Publishing House.

The 2009 Law No. 1 on Aviation.

The 1999 Law No. 8 on Consumer Protection.

The Governement Regulation of the Republik of Indonesia No. 3 of 2001 on Aviation Safety and Security.

The Minister of Transportation Regulation Regulation No. 38 of 2015 on A Domestic Air Passenger Standard in Indonesia.

The Montreal Convention, 1999.

The Warsaw Convention, 1929.

Saratoga Group Kuasai Mandala Air, http:/bisniskeuangan.kompas.com/read/20 11//20/07112748/Saratoga.Group.Kuasai. Mandala.Air, (retrieved : July 20, 2016. Commercial Court of Central Jakarta on January 31, 2013.

Wamenhub: TransportasiUdaraLebihDiminatiDibandingkanDarat,http://indosurya research.com/details.php?go=news\&id $=6052 \_$Indosurya-Research-news Wamenhub:-Transportasi-Udara-LebihDiminati-Dibandingkan-Darat (retrieved: Aug 10, 2014).

Zeti Zuryani Mohd Zakuan, Sakina Shaik Ahmad Yusoff, and Rahmah Ismail. 2015. Akta Perlindungan Pengguna 1999 (Akta 599) Liabiliti Sivil Peniaga di Malaysia. Bangi: Penerbit Universiti Kebangsaan Malaysia. 